\title{
Formation conditions of noble metal mineralization in sulfide cobalt-copper-nickel ores of Kamchatka (on the example of Annabergitovaya Schel ore occurrence)
}

\author{
Roman M. NOVAKOV ${ }^{1} \bowtie$, Valentina E. KUNGUROVA ${ }^{1}$, Svetlana V. MOSKALEVA ${ }^{2}$ \\ ${ }^{1}$ Scientific Research Geotechnological Centre of the Far Eastern Branch of the Russian Academy of Sciences, \\ Petropavlovsk-Kamchatsky, Russia \\ ${ }^{2}$ Institute of Volcanology and Seismology of the Far Eastern Branch of the Russian Academy of Sciences, \\ Petropavlovsk-Kamchatsky, Russia
}

How to cite this article: Novakov R.M., Kungurova V.E., Moskaleva S.V. Formation conditions of noble metal mineralization in sulfide cobalt-copper-nickel ores of Kamchatka (on the example of Annabergitovaya Schel ore occurrence). Journal of Mining Institute. 2021. Vol. 248, p. 209-222. DOI: 10.31897/PMI.2021.2.5

\begin{abstract}
The authors present research results, the purpose of which is to study the specifics of noble metal mineralization and its genesis in sulfide cobalt-copper-nickel ores of the Kamchatka nickel-bearing province. The paper is dedicated to one of its many ore occurrences called Annabergitovaya Schel (Annabergite Gap). The material composition of platinoid, silver, gold, bismuth and tellurium minerals, as well as sulfarsenides in the ores of this occurrence was investigated. Based on the data of mineral formation sequence and the use of geosensors, conclusions were drawn regarding the genesis of noble metal mineralization.

Formation of platinoid minerals, silver and gold at the Annabergitovaya Schel ore occurrence is mainly associated with the epigenetic effect of post-ore granitoids on ore-bearing intrusion rocks of the Dukuk complex of the cortlanditenorite formation and on syngenetic ores. An early association of noble metal minerals is represented by sperrylite, irarsite, and rare unnamed phases of $\mathrm{Pt}+\mathrm{Ir}+\mathrm{Te}$. Irarsite and $\mathrm{Pt}+\mathrm{Ir}+\mathrm{Te}$ phases were formed at the contact-metasomatic stage. Sperrylite can be assumed to be of magmatic origin. Silver sulfides and tellurides, silver and palladium bismuth tellurides, and native gold were formed at the late, hydrothermal-metasomatic, stage. The occurrence conditions of mineral parageneses, associated with noble metal mineralization, correspond to the formation of shallow-depth metasomatic rocks $(\leq 5 \mathrm{~km})$. Sub-developed quartz-feldspar metasomatites, associated with the formation of early platinoid arsenides and sulfarsenides, are in equilibrium with circumneutral solutions ( $\mathrm{pH}$ of 4.5-6.5) at temperatures of 350$600{ }^{\circ} \mathrm{C}$. Late hydrothermal association with $\mathrm{Pd}, \mathrm{Ag}$ and $\mathrm{Au}$ minerals is close to propylites and was formed at $\mathrm{pH}$ values of 4.5-6.5 and temperature of $150-350^{\circ} \mathrm{C}$.
\end{abstract}

Key words: Kamchatka; cortlandite-norite formation; sulfide copper-nickel ores; conditions of mineral formation; platinum-group elements; gold

Introduction. Apart from being a raw material for the production of non-ferrous metals, sulfide copper-nickel ores are also an important source of platinoids [10, 13, 14, 33]. In Kamchatka, numerous ore occurrences and a medium-scale Shanuch deposit of sulfide cobalt-copper-nickel ores are located within the Kamchatka nickel-bearing province (KNP), which outlines a large block of metamorphic rocks - the Kamchatka median massif [15, 23]. It is located in the Median (Sredinny) Range, extends over $200 \mathrm{~km}$ in the meridian direction and has a width of $30-40 \mathrm{~km}$ (Fig.1). Nickel-bearing objects are associated with the developed intrusions of the Dukuk complex of the norite-cortlandite formation (or the formation of hornblende basites, according to [7]). Sulfide ores contain noble metal minerals represented by sperrylite, irarsite, palladium tellurobismuthides, merenskite, palladium antimonides, native platinum, isoferroplatinum and native gold $[11,13,15,20,22]$.

The problems concerning the genesis of sulfide copper-nickel ores and the mechanisms of metal fractionation, the ratios of ore minerals, the forms of occurrence and distribution of platinum group elements (PGEs) and gold in ore bodies retain their relevance to this day [3, 4, 16, 24, 28, 29]. The genesis of cobalt-copper-nickel ores in the KNP is a debatable issue. According to most researchers, their formation is determined by magmatic processes [8, 11, 17-19, 22]. For example, for Kvinum I and II ore occurrences, it is assumed that formation of sulfide and noble metal mineralization is determined by magmatic differentiation and sulfurization under the influence of fluids. Moreover, the 


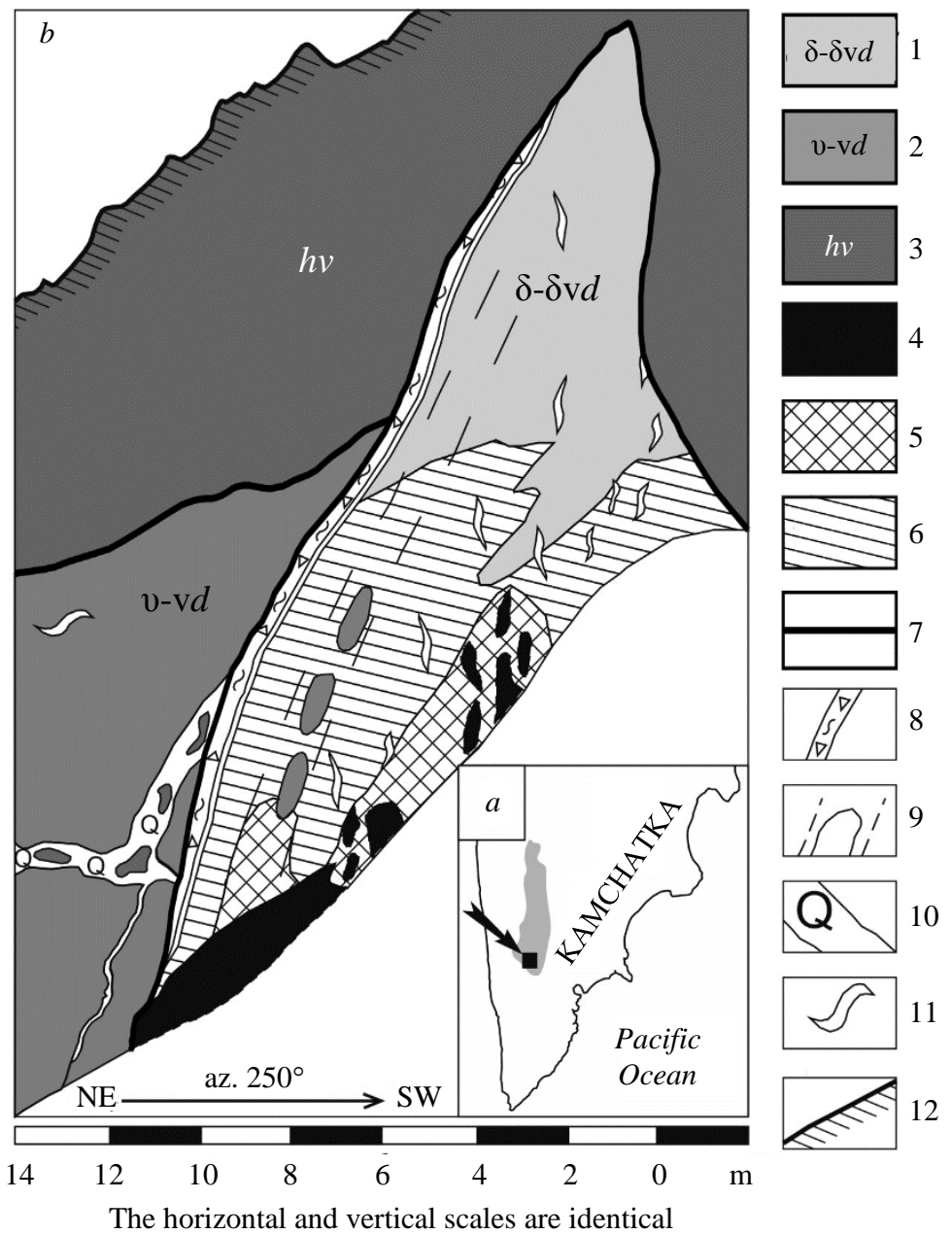

Fig.1. Geological structure of the Annabergitovaya Schel occurrence: $a$ - an overview map, an arrow indicates the location of the Annabergitovaya Schel ore occurrence, the KNP is highlighted in grey; $b-$ a sketch of the outcrop (according to [20], with modifications)

1, 2 - intrusive formations of the Dukuk complex (Eocene): hybrid rocks, mostly melanocratic diorites and diorites (1), ultramafites, gabbronorites, norites, diorites (2); 3 - schists of the Kheivan formation

(Early-Late Cretaceous); 4-6 - ore types: massive ores (4), vein-disseminated and nested ores (5), disseminated ores (6); 7 - rupture faults;

8 - zones of fragmentation and foliation; 9 - zones of boudinage; 10 - zone of brecciation with quartz-feldspar cement; 11 - quartz-feldspar veins with sulfide disseminations; 12 - edge of the steep slope of the stream productivity in relation to PGEs increases with the growing role of Te, As, $\mathrm{Sb}$ and $\mathrm{Bi}$ in the fluids $[11,22]$. At the same time, many researchers point to metamorphic, metasomatic and hydrothermal transformations of coppernickel ores in the KNP $[5,12,15]$.

This paper discusses one of the many KNP ore occurrences - Annabergitovaya Schel (Annabergite Gap). Its geological structure, chemical and mineral composition of ores are described in a number of publications [5, $9,15,20]$. The ore mineral associations, identified at the Annabergitovaya Schel occurrence, were previously found at the Shanuch deposit [13] and resemble the associations of the Dambukinsky nickel-bearing area in the Upper Amur Region [21]. The composition of platinoid, silver and gold minerals is close to the noble metal mineralization in the ore body N 1 of the Shanuch deposit [13], as well as in the ore occurrences in the southern part of the KNP - Kvinum I [11] and Kvinum II [21].

The purpose of the study within the scope of this paper was to identify the specifics of material composition and genesis of noble metal mineralization at the Annabergitovaya Schel ore occurrence. New data were obtained on the composition and ratios of minerals, which made it possible to draw conclusions about the genesis of PGE, silver and gold minerals.

Research methods. In the process of studying the ores of the Annabergitovaya Schel occurrence, data on their chemical composition were obtained [20], mineralogical tests were performed using electron microscopy and X-ray diffractometry. To assess the formation conditions of noble metal minerals, authors used geothermometers, available data on thermodynamic properties of the associated minerals and results of summarizing studies [1].

Detection of $\mathrm{Ni}, \mathrm{Cu}, \mathrm{Co}$ and $\mathrm{Au}$ was carried out using the atomic absorption method on a Shumadzu AA-6300 spectrometer at the Scientific Research Geotechnological Centre of the Far Eastern Branch of the Russian Academy of Sciences (SRGC FEB RAS). Pt and Pd were detected by the method of atomic emission spectrometry with inductively coupled plasma on an IRIS Intrepid Duo spectrometer at the Vernadsky Institute of Geochemistry and Analytical Chemistry of the Russian Academy of Sciences. Ag was detected by means of spectral analysis at the Institute of Mineralogy, Geochemistry and Crystal Chemistry of Rare Elements.

Studies of the chemical composition of the minerals and microphotography were performed at the Institute of Volcanology and Seismology of the Far Eastern Branch of the Russian Academy of Sciences on a Tescan Vega 3 scanning electron microscope with an energy dispersive spectrometer 
Oxford Instruments X-Max $80 \mathrm{~mm}^{2}$ and AZtec software. As for the reference samples, PGEs were compared to pure metals, obtained at the Moscow State Institute of Steel and Alloys, while Au, Ag, $\mathrm{Ni}$ and $\mathrm{Fe}$ were compared to the corresponding metals. Artificial compounds $\mathrm{FeAsS}$ and $\mathrm{FeS}_{2}$ were used for As and $\mathrm{S}$ detection; synthetic minerals $\mathrm{CdTe}, \mathrm{CuSbS}_{2}, \mathrm{Bi}_{2} \mathrm{~S}_{3}, \mathrm{PbS}, \mathrm{ZnS}, \mathrm{CuFeS}_{2}-$ for Te, $\mathrm{Sb}, \mathrm{Bi}, \mathrm{Pb}, \mathrm{Zn}, \mathrm{Cu}$; a Fe-Co-Ni alloy of known composition - for Co. The tests were carried out using accelerating voltage of $20 \mathrm{kV}$ and absorbed current on the nickel reference sample of $700 \mathrm{pA}$.

Certain samples of ore and rock powders were studied at the SRGC FEB RAS on a Rigaku Ultima IV powder X-ray diffractometer with horizontal sample fixation. A glass cuvette was used as a sample holder. Diffraction patterns of the sample powders were recorded using a D/tex detector in the $2 \Theta$ range of $10-100^{\circ}$, at a speed of $1.0^{\circ} / \mathrm{min}$, in standard mode. The crystalline phases were identified using the ICDD PDF-2 (Powder Diffraction File) database (version 2012) updated in 2019 and PDXL-2 software package.

Research results. Geological structure of the ore occurrence, mineralogy and ore geochemistry. Annabergitovaya Schel, an occurrence of rich sulfide cobalt-copper-nickel ores, is located in the southern part of the KNP (Fig. 1, a), in the upper reaches of the river Stepanova (53 $24^{\prime} 56.1^{\prime \prime} \mathrm{N}$ and $157^{\circ} 4^{\prime} 3.4^{\prime \prime} \mathrm{E}$ ). The ore body outcrops in a narrow glen, formed along the rupture fault zone. The length of the ore outcrop is $18 \mathrm{~m}$ along the thalweg; the height of the western vertical edge is $11 \mathrm{~m}$ (Fig. 1, b). The ore body is composed of massive, vein-disseminated, nested and disseminated sulfide ores. The contacts with the host rocks are tectonic, with zones of fragmentation, boudinage and foliation [20]. Massive unoxidized ores contain on average $4.82 \mathrm{wt} \%$ of $\mathrm{Ni}, 1.95 \mathrm{wt} . \%$ of $\mathrm{Cu}$ and 0.13 wt. \% of Co, as well as $0.036 \mathrm{~g} / \mathrm{t}$ of Pt and $1.12 \mathrm{~g} / \mathrm{t}$ of Pd. The Au content reaches $0.08 \mathrm{~g} / \mathrm{t}$, the $\mathrm{Ag}$ concentration is on average $6.66 \mathrm{~g} / \mathrm{t}$ [20].

The ores are associated with the Dukuk complex intrusion - a deformed sill-like body a few tens of meters thick in the apoterrigenous schists of the Kheivan formation, metamorphosed under the conditions of greenschist and amphibolite facies [5]. The intrusion is composed of predominant highly altered ultramafites (probably, olivine websterites [15]), as well as gabbronorites, norites and diorites (Fig.1,b). These rocks and their syngenetic associates were transformed as a result of contact metamorphism and metasomatose under the influence of nearby post-ore intrusions of granitoids [12], which on a 1:1,000,000-scale geological map are attributed to the second phase of the Kola plagiogranite-grandiorite complex [5]. At the ore occurrence, there is a wide representation of hybrid rocks, their composition varying from melanocratic diorites to biotite-hornblende plagiogranites. The ore body and the surrounding schists intersect associated with granitoids veins of quartz, quartz-feldspar, sometimes muscovite, which are a few centimeters in thickness. Quartz-feldspar areas with a micropegmatitic structure are typical for hybrid rocks, granitoids and veins.

The main ore minerals are pyrrhotite (predominantly monoclinic, 6C), chalcopyrite and pentlandite. Pyrite and marcasite are common. Hypergene minerals are widespread, such as iron hydroxides, morenosite, retgersite, malachite and azurite. As for rare minerals, it was detected that the ores contained nickel and cobalt sulfarsenides, galena, sphalerite, as well as compounds of bismuth and tellurium [20]. X-ray diffraction studies of the ores revealed the presence of cobaltpentlandite, nickel-bearing pyrite, bornite, covellite, colusite and scheelite. Minerals of noble metals are mainly represented by sperrylite [15] and irarsite. Hessite and volynskite are less developed [20]. Native gold and argentopentlandite are occasionally found [20], as well as michenerite [15].

Mineral associations. Ore minerals form three mineral associations (or parageneses, according to [9]), which are also typical for the Shanuch ore field [13]: pentlandite-pyrrhotite, pyrrhotite-pentlandite-chalcopyrite and pyrite-marcasite ones [9]. The associations are distinguished according to the specifics of their mineral composition, taking into account quantitative ratios of ore minerals and their morphology. They partially characterize the sequence of ore formation and reflect primary zonality of sulfide ores, which is formed at the magmatic stage in the process of sulfide melt differentiation [10]. 
Pentlandite-pyrrhotite association, the formation of which is attributed to the magmatic stage, is represented by sulfides of the early generation (I): porphyry segregations of pentlandite and pyrrhotite with reticulate pentlandite [9]. At the Shanuch ore field, the composition of this association also includes early chalcopyrite I [13]. At the studied ore occurrence, the association is weakly developed, which possibly reflects primary zonality of sulfide ores, formed in the process of magmatic differentiation of the sulfide melt.

Pyrrhotite-pentlandite-chalcopyrite association is represented by pyrrhotite with flame- and plate-like segregations of pentlandite II, chalcopyrite II, sulfarsenides of nickel and cobalt (I), sperrylite and irarsite. The association is formed as a result of syngenetic processes and subsequent transformations under the influence of post-ore granitoids of the Kola complex. Contact changes in igneous rocks of the Dukuk complex intrusion are manifested in the replacement of primary plagioclase by albite and replacement of tschermakites, pargasites, pyroxenes and olivines by magnesio-hornblende, anthophyllite, cummingtonite, as well as aggregates of these amphiboles, including segregations of sphene and rutile. As a result of contact-metasomatic transformations (sub-developed quartzfeldspar metasomatose), an aggregate of oligoclase, potassium feldspar and quartz is represented in some areas of the ore body; a replacement of phlogopite by biotite is observed, as well as replacement of early amphibole aggregates by quartz and feldspars.

Pyrite-marcasite association is formed in the process of subsequent hydrothermal-metasomatic transformation of the minerals in early sulfide associations: pentlandite is replaced by violarite, pyrrhotite - by pyrite and marcasite. Notably, pyrrhotite, which occurs in paragenesis with pyrite and marcasite, is characterized by higher sulfur content. Redistribution of chalcopyrite I and II led to the formation of its late variation (chalcopyrite III [13, 21]). Galena, native gold, volynskite, hessite, argentopentlandite and tellurium-bismuth mineralization were also formed at this stage. The silicates were replaced by clinochlore, epidote, actinolite and sphene, in some areas - by talc and carbonate.

Specifics of noble metal mineralization. Early and late noble metal mineralizations are distinguished at the ore occurrence. The early one belongs to the pyrrhotite-pentlandite-chalcopyrite association and is represented by sperrylite, irarsite and an unnamed compound of Pt, Ir and Te. Early minerals of noble metals are spatially and genetically related to sulfarsenides of the cobaltite group, which often contain isomorphic traces of platinoids. The presence of gersdorfite is confirmed by Xray diffractometry results. The late mineralization belongs to the pyrite-marcasite association and is represented by michenerite, volynskite, hessite, argentopentlandite, native gold and Ag-containing tellurobismuthite (Table 1).

Table 1

Noble metal minerals and minerals, containing noble metals in isomorphic form, detected at the Annabergitovaya Schel ore occurrence

\begin{tabular}{|c|c|c|}
\hline No. & Mineral & Chemical formula \\
\hline \multicolumn{3}{|c|}{ Platinoid minerals } \\
\hline 1 & Sperrylite & $\mathrm{PtAs}_{2}$ \\
\hline 2 & Irarsite & IrAsS \\
\hline 3 & Michenerite & PdBiTe \\
\hline \multicolumn{3}{|c|}{ Silver and gold minerals } \\
\hline 4 & Volynskite & $\mathrm{AgBiTe}_{2}$ \\
\hline 5 & Argentopentlandite & $\mathrm{Ag}(\mathrm{Fe}, \mathrm{Ni})_{8} \mathrm{~S}_{8}$ \\
\hline 6 & Hessite & $\mathrm{Ag}_{2} \mathrm{Te}$ \\
\hline 7 & Native gold & $\mathrm{Au}, \mathrm{Ag}$ \\
\hline \multicolumn{3}{|c|}{ Minerals, containing noble metals in isomorphic form } \\
\hline $\begin{array}{l}8 \\
9\end{array}$ & $\begin{array}{l}\text { Sulfarsenides (cobaltite-gersdorfite series) } \\
\text { Tellurobismuthite }\end{array}$ & $\begin{array}{c}\text { NiAsS, traces of } \mathrm{Co}, \mathrm{Fe}, \mathrm{Ir}, \mathrm{Pt}, \mathrm{Rh}, \mathrm{Pd} \\
\mathrm{Bi}_{2} \mathrm{Te}_{3} \text {, traces of } \mathrm{Ag}, \mathrm{Pb}\end{array}$ \\
\hline
\end{tabular}

Early noble metal mineralization. Sperrylite and irarsite form round or platy inclusions in sulfarsenides (intermediate members of the cobaltite-gersdorfite series). The size of sperrylite segregations varies from 2.5 to $2 \mu \mathrm{m}$, their composition is close to the theoretical formula (Table 2). The size 
of irarsite inclusions ranges from 2 to $5 \mu \mathrm{m}$ (Fig.2, $d$ ), the mineral usually contains traces of Pt (on average $5.22 \mathrm{wt} . \%$ ) and $\mathrm{Rh}$ (on average $1.85 \mathrm{wt} . \%)$.

Sperrylite and irarsite compositions (calculated as $100 \mathrm{wt} \%$ )

\begin{tabular}{|c|c|c|c|c|c|c|c|c|}
\hline No. & $\mathrm{Pt}$ & $\mathrm{Rh}$ & Ir & $\mathrm{Pd}$ & As & $\mathrm{S}$ & Total & Empirical formula \\
\hline 1 & 53.88 & - & - & - & 46.12 & - & 100.00 & $\mathrm{Pt}_{0.93 \mathrm{As} 2.07}$ \\
\hline 2 & 58.73 & - & - & - & 41.27 & - & 100.00 & $\mathrm{Pt}_{1.06} \mathrm{As}_{1.94}$ \\
\hline 3 & 56.96 & - & - & - & 43.04 & - & 100.00 & $\mathrm{Pt}_{1.01} \mathrm{As}_{1.99}$ \\
\hline 4 & 55.88 & - & - & - & 44.12 & - & 100.00 & $\mathrm{Pt}_{0.98} \mathrm{As}_{2.02}$ \\
\hline 5 & 56.15 & - & - & - & 43.85 & - & 100.00 & $\mathrm{Pt}_{0.99} \mathrm{As}_{2.01}$ \\
\hline 6 & 52.15 & & 4.49 & - & 43.36 & - & 100.00 & $\mathrm{Pt}_{0.92} \mathrm{Ir}_{0.08} \mathrm{As}_{2.00}$ \\
\hline \multicolumn{9}{|c|}{ Average values $(n=15)$} \\
\hline & 56.00 & - & 0.30 & - & 43.71 & - & 100.00 & $\mathrm{Pt}_{0.99} \mathrm{Ir}_{0.01} \mathrm{As}_{2.01}$ \\
\hline 7 & 7.57 & 1.68 & 51.13 & - & 29.69 & 9.92 & 100.00 & $\left(\operatorname{Ir}_{0.75} \mathrm{Pt}_{0.11} \mathrm{Rh}_{0.05}\right)_{0.91} \mathrm{As}_{1.12} \mathrm{~S}_{0.88}$ \\
\hline 8 & - & 7.80 & 50.61 & - & 30.93 & 10.66 & 100.00 & $\left(\operatorname{Ir}_{0.71} \mathrm{Rh}_{0.2}\right)_{0.91} \mathrm{As}_{1.11} \mathrm{~S}_{0.89}$ \\
\hline 9 & 6.39 & 2.84 & 51.62 & - & 27.94 & 11.22 & 100.00 & $\left(\operatorname{Ir}_{0.74} \mathrm{Pt}_{0.09} \mathrm{Rh}_{0.08}\right)_{0.91} \mathrm{As}_{1.03} \mathrm{~S}_{0.97}$ \\
\hline 10 & 7.24 & 1.01 & 51.72 & 0.76 & 28.85 & 10.42 & 100.00 & $\left(\mathrm{Ir}_{0.76} \mathrm{Pt}_{0.10} \mathrm{Rh}_{0.03} \mathrm{Pd}_{0.02}\right)_{0.91} \mathrm{As}_{1.08} \mathrm{~S}_{0.92}$ \\
\hline \multicolumn{9}{|c|}{ Average values $(n=10)$} \\
\hline & 4.82 & 2.64 & 53.16 & 0.08 & 28.36 & 10.95 & 100.00 & $\left(\mathrm{Ir}_{0.77} \mathrm{Rh}_{0.07} \mathrm{Pt}_{0.07}\right)_{0.91} \mathrm{As}_{1.05} \mathrm{~S}_{0.95}$ \\
\hline
\end{tabular}

Note. 1-6 - sperrylite; 7-10 - irarsite. Empirical formula (Pt, Rh, Ir) ${ }_{0.91}$ AsS was used to calculate formula coefficients for irarsite. In the process of microprobe analysis, due to the small size of PGE phases, the beam also "captured" the gersdorfite matrix and probably thin microinclusions: gersdorfite and irarsite in sperrylite, gersdorfite in irarsite. When converting results to $100 \mathrm{wt} \%$ and calculating the formulas, these "captured" phases were excluded.

Sulfarsenides associated with platinoids form idiomorphic crystals up to $0.1-0.5 \mathrm{~mm}$ in size, which are usually confined to the grain borders of main ore-forming sulfides and often have an isometric hexagonal shape of the cross-section (Fig.2, $b, g$ ). Small grains of sulfarsenides are usually observed in chalcopyrite, while larger grains are found in pyrrhotite. Less often their inclusions are detected in pentlandite, pyrite and violarite. The crystals of sulfarsenides in pyrrhotite are characterized by flame-like segregations of pentlandite that form along their edges (Fig.2, a).

The ratios and the segregation sequence of sperrylite, irarsite and Fe-Co-Ni sulfarsenides were examined in an epitaxial intergrowth of these minerals, located at the border of the violarite grain (Fig.3, $a-d$ ). Inside the hexagonal crystal of Fe-Co-Ni sulfarsenide, there is an elongated sperrylite crystal with irarsite-rimmed edge, in which an unnamed compound of Te, Ir and Pt is detected (Fig.3, $c-f)$. An idiomorphic, probably cubic mineral of the cobaltite-gersdorfite series with platinoids (hereinafter referred to as sulfarsenide I) is naturally rimmed by sulfarsenide of the second generation (sulfarsenide II) with increased Co content. Its rhombic cross-section also has an idiomorphic outline. It is can possibly be a nickel-containing glaucodot (rhombic).

On the cross-section through this intergrowth (Fig.3,g), one can observe the absence of zonality and relatively constant compositions of sulfarsenides I and II. With sulfarsenides of both generations having almost equal contents of As and $\mathrm{S}$, the differences in their compositions are manifested in varying ratios of $\mathrm{Ni}$ and $\mathrm{Co}$ with insignificant changes in the $\mathrm{Fe}$ content (Fig.3, g). In addition to inclusions of platinoid minerals, sulfarsenide I may contain their traces (Table 3), probably as a result of isomorphic substitution: $\mathrm{Rh}-$ up to $0.83 \mathrm{wt} \%, \mathrm{Pd}-$ up to $0.53 \mathrm{wt}$. \%, $\mathrm{Pt}-$ up to $0.54 \mathrm{wt} \%$, $\mathrm{Ir}$ - up to $2.56 \mathrm{wt} . \%$. Moreover, sulfarsenide I is observed to contain $\mathrm{Cu}$ (up to $1.67 \mathrm{wt} \%$ ), as well as Se (up to $0.32 \mathrm{wt} . \%$ ) and Te (up to $0.32 \mathrm{wt} . \%$ ). Sulfarsenide II is characterized by the absence of platinoids, increased Co content (around $17 \mathrm{wt} . \%$ ) and a close to constant ratio of Ni/Fe contents (Fig.4). 


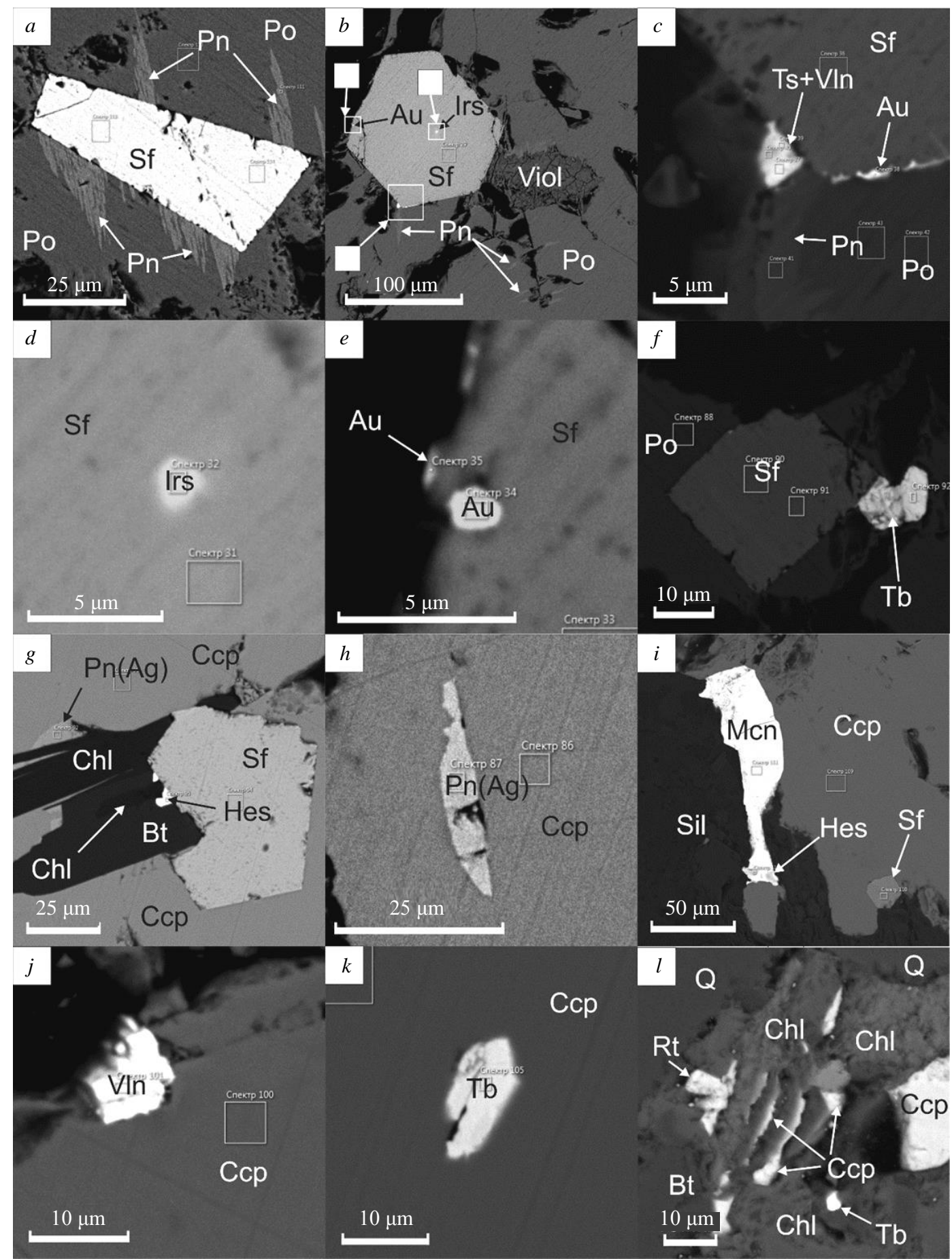

Fig.2. Ratios of noble metal minerals and tellurobismuthides to sulfarsenides, main sulfides, violarite, biotite, quartz and clinochlore (all images are generated from backscattered electrons):

$a$ - flame-like segregations of pentlandite ( $\mathrm{Pn}$ ) in pyrrhotite ( $\mathrm{Po}$ ) along the faces of sulfarsenide crystal (Sf); $b$-idiomorphic crystal of sulfarsenide with a thin inclusion of irarsite (Irs) in pyrrhotite, which contains flame-like growths of pentlandite and an area replaced by violarite (Viol); $c$ - magnified image of the sulfarsenide crystal edge, rimmed by thin aggregate compounds of bismuth and tellurium, probably volynskite and tsumoite $(\mathrm{Ts}+\mathrm{Vln})$, as well as native gold $(\mathrm{Au})$;

$d$ - magnified fragment of the sulfarsenide crystal with an irarsite inclusion; $e$ - magnified fragment of the sulfarsenide crystal edge with gold segregations; $f$-pyrrhotite (with composition close to $\mathrm{Fe}_{6} \mathrm{~S}_{7}$ ) includes an idiomorphic crystal of sulfarsenide with a grain of tellurobismuthite $(\mathrm{Tb})$, developing along one of its faces;

$g$ - chalcopyrite (Ccp) includes a sulfarsenide crystal, xenomorphic in relation to biotite (Bt) and idiomorphic in relation to chlorite (Chl) and chalcopyrite; a thin aggregate of hessite (Hes) is observed on one of sulfarsenide faces near the contact with chlorite;

argentopentlandite $(\mathrm{Pn}(\mathrm{Ag}))$ develops on the contact with silicates (Sil) in chalcopyrite; $h$-inclusion of argentopentlandite in chalcopyrite (probably, along the healed fracture); $i$ - michenerite (Mcn) with a thin inclusion of hessite, developing along the edge area of chalcopyrite grain; $j$ - volynskite (Vln) in chalcopyrite; $k$-idiomorphic crystal of tellurobismuthite in chalcopyrite; $l$ - biotite $(\mathrm{Bt})$ intergrown with quartz $(\mathrm{Q})$, being replaced by the clinochlore aggregate, which contains platy segregations of late generation chalcopyrite, thin inclusions of tellurobismuthite and rutile (Rt) 


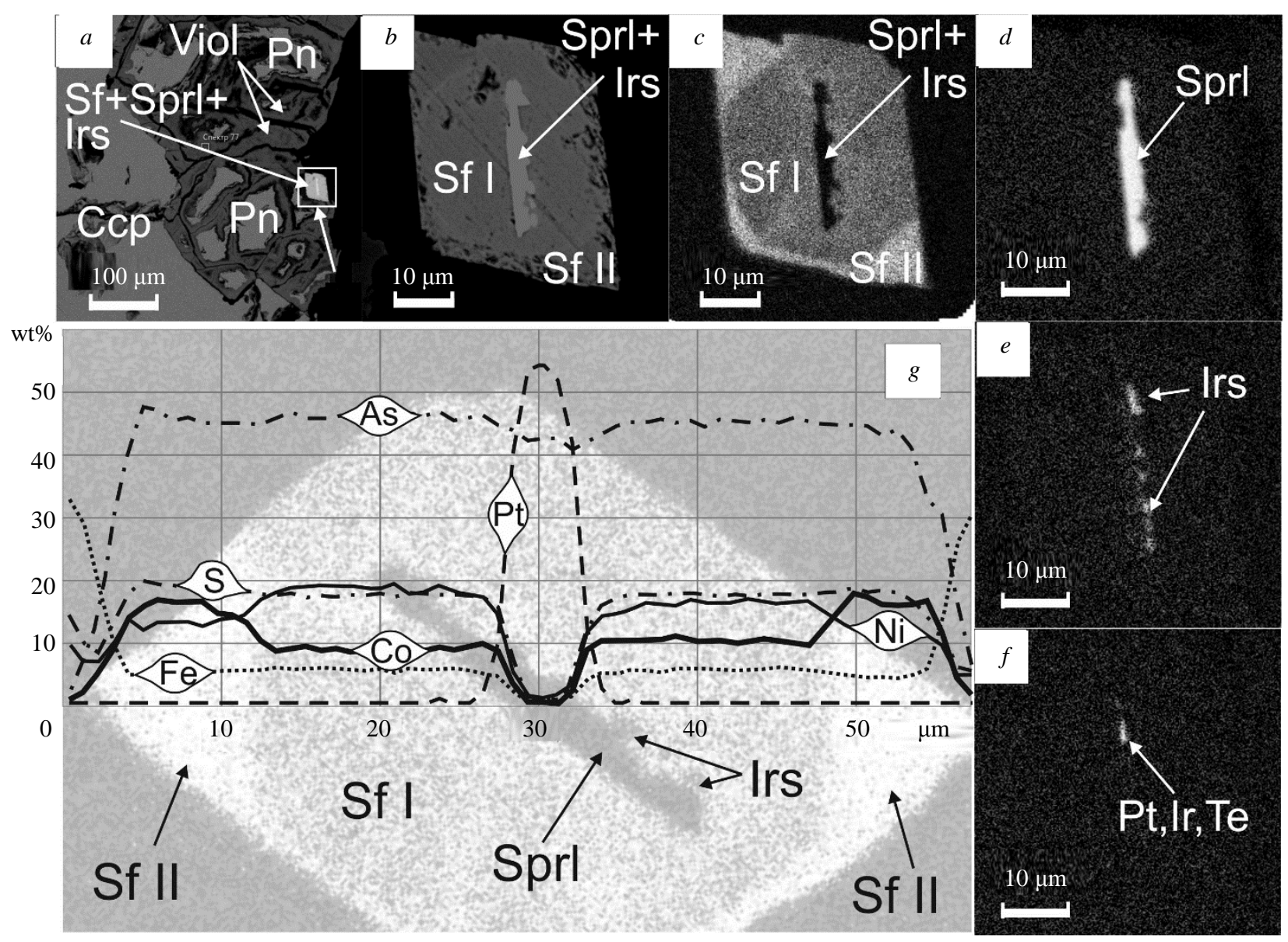

Fig.3. Epitaxial intergrowth of sperrylite, irarsite and Fe-Co-Ni sulfarsenide crystals (all images are generated from backscattered electrons):

$a$ - proportion of the intergrowth of sulfarsenides, sperrylite and irarsite $(\mathrm{Sf}+\mathrm{Sprl}+\mathrm{Irs})$ to chalcopyrite $(\mathrm{Ccp})$, pentlandite $(\mathrm{Pn})$, violarite (Viol); $b$ - magnified fragment with the intergrowth of sulfarsenides and sperrylite, where the crystal of sulfarsenide II (Sf II, glaucodot) is rimmed by idiomorphic sulfarsenide I (Sf I, cobaltite-gersdorfite series), in the central part of which there is an intergrowth of sperrylite and irarsite (Sprl + Irs); $c, d, e, f$ - the intergrowth in beams of cobalt (contours of sulfarsenide I, sulfarsenide II and PGE crystals, c), platinum (sperrylite, d), iridium (irarsite, e), tellurium (unnamed phase, a compound of tellurium, platinum and iridium, f); $g-$ a cross-section through the intergrowth of sulfarsenides and sperrylite.

An image in cobalt beams was used as an underlay for the cross-section.

Contents of $\mathrm{S}, \mathrm{As}, \mathrm{Fe}, \mathrm{Co}, \mathrm{Pt}, \mathrm{Ni}$ are expressed in weight percentage.

Compositions of sulfarsenides (wt.\%)

\begin{tabular}{c|c|c|c|c|c|c|c|c|c|c|c|c}
\hline No. & $\mathrm{S}$ & $\mathrm{As}$ & $\mathrm{Fe}$ & $\mathrm{Co}$ & $\mathrm{Ni}$ & $\mathrm{Cu}$ & $\mathrm{Rh}$ & $\mathrm{Pd}$ & $\mathrm{Pt}$ & $\mathrm{Ir}$ & Total & \multicolumn{1}{|c}{ Empirical formula } \\
\hline 1 & 17.80 & 47.53 & 5.23 & 5.86 & 23.71 & - & - & - & - & - & 100.13 & $\left(\mathrm{Ni}_{0.68} \mathrm{Co}_{0.17} \mathrm{Fe}_{0.16}\right)_{1.00} \mathrm{As}_{1.06} \mathrm{~S}_{0.93}$ \\
2 & 18.20 & 46.92 & 6.17 & 7.67 & 21.16 & - & - & - & - & - & 100.11 & $\left(\mathrm{Ni}_{0.60} \mathrm{Co}_{0.22} \mathrm{Fe}_{0.18}\right)_{1.00} \mathrm{As}_{1.05} \mathrm{~S}_{0.95}$ \\
3 & 17.88 & 46.62 & 6.81 & 9.00 & 19.55 & - & - & - & - & - & 99.85 & $\left(\mathrm{Ni}_{0.56} \mathrm{Co}_{0.26} \mathrm{Fe}_{0.20}\right)_{1.02} \mathrm{As}_{1.04} \mathrm{~S}_{0.94}$ \\
4 & 18.34 & 46.61 & 6.16 & 10.42 & 17.77 & - & - & - & - & - & 99.30 & $\left(\mathrm{Ni}_{0.51} \mathrm{Co}_{0.30} \mathrm{Fe}_{0.18}\right)_{0.99} \mathrm{As}_{1.05} \mathrm{~S}_{0.96}$ \\
5 & 18.38 & 44.94 & 6.41 & 11.32 & 17.30 & 1.67 & - & - & - & - & 100.02 & $\left(\mathrm{Ni}_{0.49} \mathrm{Co}_{0.32} \mathrm{Fe}_{0.19} \mathrm{Cu}_{0.04}\right)_{1.05} \mathrm{As}_{1.00} \mathrm{~S}_{0.95}$ \\
6 & 18.14 & 46.74 & 6.29 & 8.93 & 19.01 & - & 0.41 & - & - & - & 99.53 & $\left(\mathrm{Ni}_{0.55} \mathrm{Co}_{0.26} \mathrm{Fe}_{0.19} \mathrm{Rh}_{0.01}\right)_{1.00} \mathrm{As}_{1.05} \mathrm{~S}_{0.95}$ \\
7 & 17.90 & 45.94 & 5.92 & 9.26 & 18.44 & - & 0.82 & - & - & - & 98.28 & $\left(\mathrm{Ni}_{0.54} \mathrm{Co}_{0.27} \mathrm{Fe}_{0.18} \mathrm{Rh}_{0.01}\right)_{1.00} \mathrm{As}_{1.05} \mathrm{~S}_{0.95}$ \\
8 & 18.34 & 46.15 & 5.86 & 10.79 & 16.63 & - & 0.83 & 0.34 & 0.54 & - & 99.46 & $\left(\mathrm{Ni}_{0.48} \mathrm{Co}_{0.31} \mathrm{Fe}_{0.18} \mathrm{Pt}_{0.01} \mathrm{Rh}_{0.01} \mathrm{Pd}_{0.01}\right)_{0.99} \mathrm{As}_{1.04} \mathrm{~S}_{0.97}$ \\
9 & 17.31 & 45.26 & 4.92 & 6.21 & 22.29 & - & 0.51 & 0.53 & - & 2.56 & 99.60 & $\left(\mathrm{Ni}_{0.66} \mathrm{Co}_{0.18} \mathrm{Fe}_{0.15} \mathrm{Rh}_{0.01} \mathrm{Ir}_{0.02} \mathrm{Pd}_{0.01}\right)_{1.03} \mathrm{As}_{1.04} \mathrm{~S}_{0.93}$ \\
10 & 18.79 & 46.07 & 4.89 & 17.07 & 13.08 & - & - & - & - & - & 99.91 & $\left(\mathrm{Ni}_{0.37} \mathrm{Co}_{0.48} \mathrm{Fe}_{0.15}\right)_{1.00} \mathrm{As}_{1.02} \mathrm{~S}_{0.98}$ \\
11 & 18.86 & 44.68 & 4.89 & 16.87 & 12.89 & - & - & - & - & - & 98.2 & $\left(\mathrm{Ni}_{0.37} \mathrm{Co}_{0.48} \mathrm{Fe}_{0.15}\right)_{1.00} \mathrm{As}_{1.01} \mathrm{~S}_{0.99}$
\end{tabular}

Note. 1-9 - sulfarsenide I (cobaltite-gersdorfite series), 10, 11 - sulfarsenide II (glaucodot). 


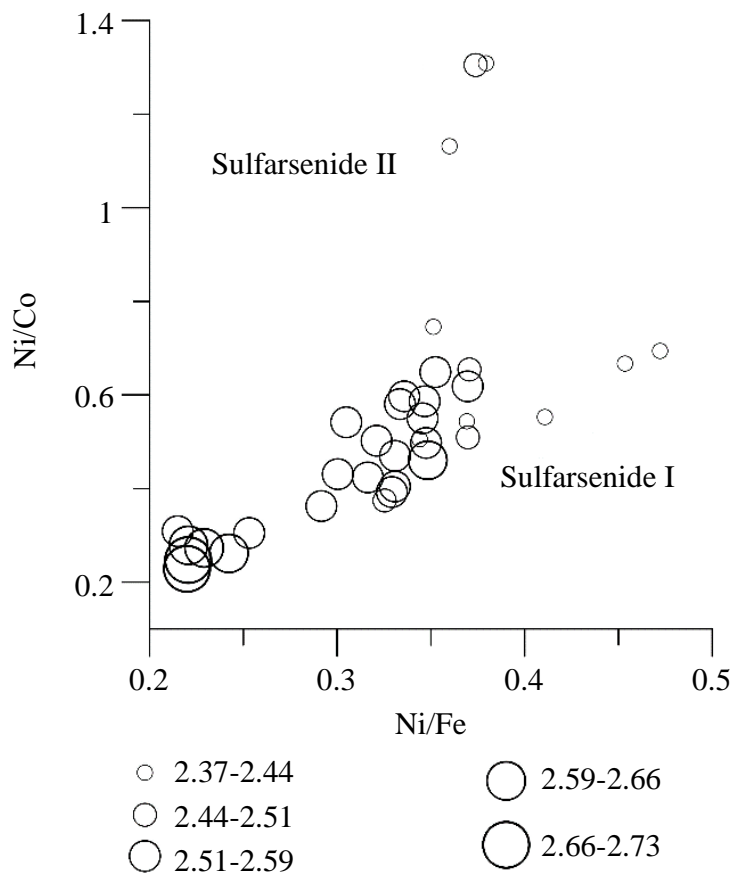

Fig.4. Ratios of Ni/Co and Ni/Fe in sulfarsenides I and II. Values of $\mathrm{Ni} / \mathrm{Co}, \mathrm{Ni} / \mathrm{Fe}$ were calculated using element contents in weight percentage.

Data from 35 tests are presented, including the compositions from Table 3.

The size of the circle is proportional to the ratio of As/S
Late noble metal mineralization (Table 4). Aggregates of bismuth and tellurium compounds, including hessite, are found in chalcopyrite and clinochlore aggregates rimming the edges of idiomorphic crystals of sulfarsenide I (see Fig.2, $b, c, f, g$ ). The size of hessite segregations equals $1-10 \mu \mathrm{m}$. In addition to that, hessite is detected in the form of inclusions in michenerite, a single segregation of which has an elongated shape of $120 \times 25 \mu \mathrm{m}$ and develops along the edge of the chalcopyrite grain (Fig.2, g).

Apart from hessite, Ag minerals are represented by argentopentlandite and volynskite. Argentopentlandite forms segregations of $15-30 \mu \mathrm{m}$, develops along the fractures in chalcopyrite and in the edge areas of its grains (Fig.2, $g, h$ ). The Ag content in argentopentlandite ranges from 8.91 to $12.98 \mathrm{wt} \%$, on average it equals $11.61 \mathrm{wt} . \%(n=8)$. Volynskite is represented by single small (up to $10 \mu \mathrm{m}$ ) inclusions in chalcopyrite (Fig.2, j); it also forms thin aggregates with tsumoite (?), rimming the edge of sulfarsenide I (Fig.2, c). A negligible amount of Ag (from 0.55 to $6 \mathrm{wt} . \%$ ) is present in tellurobismuthite, which forms idiomorphic crystals of about $15 \mu \mathrm{m}$ in chalcopyrite (Fig.2, $k$ ) and inclusions of about $3 \mu \mathrm{m}$ in chlorite (Fig.2, $l$ ).

Compositions of late noble metal minerals (wt.\%)

\begin{tabular}{c|c|c|c|c|c|c|c|c|c|c|c|c|c}
\hline No. & $\mathrm{S}$ & $\mathrm{Fe}$ & $\mathrm{Co}$ & $\mathrm{Ni}$ & $\mathrm{Cu}$ & $\mathrm{As}$ & $\mathrm{Ag}$ & $\mathrm{Te}$ & $\mathrm{Pd}$ & $\mathrm{Pb}$ & $\mathrm{Bi}$ & $\mathrm{Total}$ & \multicolumn{1}{c}{ Empirical formula } \\
\hline 1 & 31.64 & 32.93 & - & 22.33 & 1.05 & - & 12.03 & - & - & - & - & 99.98 & $\left(\mathrm{Ag}_{0.91} \mathrm{Cu}_{0.14}\right)_{1.05}\left(\mathrm{Fe}_{4.81} \mathrm{Ni}_{3.10}\right)_{7.91} \mathrm{~S}_{8.04}$ \\
2 & 31.67 & 34.7 & - & 23.11 & 1.75 & - & 8.91 & - & - & - & - & 100.14 & $\left(\mathrm{Ag}_{0.67} \mathrm{Cu}_{0.23}\right)_{0.89}\left(\mathrm{Fe}_{4.99} \mathrm{Ni}_{3.17}\right)_{8.16} \mathrm{~S}_{7.95}$ \\
3 & & 0.32 & - & - & 0.85 & - & 60.81 & 36.81 & - & - & - & 98.78 & $\mathrm{Ag}_{1.99} \mathrm{Te}_{1.01}$ \\
4 & 4 & 4.68 & 1.81 & 1.52 & - & 8.13 & 49.21 & 31.17 & - & - & - & 100.51 & $\mathrm{Ag}_{1.95} \mathrm{Te}_{1.05}$ \\
5 & - & 1.75 & - & - & 2.5 & - & 16.3 & 42.74 & - & - & 35.87 & 99.17 & $\left(\mathrm{Ag}_{0.71} \mathrm{Cu}_{0.26}\right)_{0.97} \mathrm{Bi}_{1.10} \mathrm{Te}_{1.87}$ \\
6 & - & 2.11 & - & - & 2.81 & - & 13.12 & 40.97 & - & 1.8 & 39.49 & 100.31 & $\left(\mathrm{Ag}_{0.87} \mathrm{Cu}_{0.22}\right)_{1.09} \mathrm{Bi}_{0.99} \mathrm{Te}_{1.92}$ \\
7 & - & 0.92 & - & - & - & - & 0.55 & 48.61 & - & - & 48.95 & 99.04 & $\left(\mathrm{Bi}_{1.89} \mathrm{Ag}_{0.04} \mathrm{~Pb}_{0.00}\right)_{1.93} \mathrm{Te}_{3.07}$ \\
8 & - & 2.54 & - & - & - & - & 1.53 & 46.21 & - & 3.3 & 45.19 & 98.76 & $\left(\mathrm{Bi}_{1.78} \mathrm{Ag}_{0.12} \mathrm{~Pb}_{0.13}\right)_{2.02} \mathrm{Te}_{2.98}$ \\
9 & - & 2.37 & - & - & - & - & 6.00 & 47.02 & - & 2.39 & 43.21 & 100.99 & $\left(\mathrm{Bi}_{1.61} \mathrm{Ag}_{0.44} \mathrm{~Pb}_{0.09}\right)_{2.14} \mathrm{Te}_{2.86}$ \\
10 & - & - & - & - & - & - & - & 31.58 & 24.42 & - & 39.57 & 98.95 & $\mathrm{Pd}_{0.99}\left(\mathrm{Sb}_{0.12} \mathrm{Bi}_{0.82}\right)_{0.94} \mathrm{Te}_{1.07}$
\end{tabular}

Note. 1, 2 - argentopentlandite; 3, 4- hessite; 5, 6 - volynskite; 7-9 - tellurobismuthite; 10 - michenerite. Formulas of volynskite (for 4 atoms), tellurobismuthite (for 5 atoms) were calculated without iron, which is probably included in the hydroxide composition.

Individual micro-inclusions of high-fineness native gold ( $93.6 \mathrm{wt} . \%$ of $\mathrm{Au}$ ) less than $2 \mu \mathrm{m}$ in size are found in chalcopyrite (Table 5). Gold ( $80 \mathrm{wt} . \%$ of $\mathrm{Au})$ in the form of segregations and a thin rim occurs on the edge of sulfarsenide I crystals (Table 5, Fig.2, $c, e$ ). A segregation of relatively low-fineness gold ( 71.5 wt.\% of Au), 6-7 $\mu \mathrm{m}$ in size, was detected in violarite (Table 5).

Estimation of formation temperatures of noble metal mineralization. Formation conditions of early platinoids were estimated based on paragenetically related sulfarsenides I using the NiAsS-FeAsS-CoAsS diagram (Fig.5, a), which shows the isotherms of solvus temperatures according to [31]. Judging from these data, sulfarsenides I were formed at the temperatures of around $400-500{ }^{\circ} \mathrm{C}$. 
Representative compositions of native gold (wt.\%)

\begin{tabular}{l|c|c|c|c|c}
\hline \multicolumn{1}{c|}{ Component } & 1 & 3 & 4 & 5 & 6 \\
\hline $\mathrm{Au}$ & 91.10 & 79.24 & 80.93 & 70.83 & 72.12 \\
$\mathrm{Ag}$ & - & 20.76 & 19.07 & 29.17 & 27.88 \\
$\mathrm{Cu}$ & 5.62 & - & - & - & - \\
$\mathrm{Fe}$ & 3.28 & - & - & - & - \\
$\mathrm{Total}$ & 100 & 100 & 100 & 100 & 100 \\
Fineness of gold, \%o & $\sim 936$ & \multicolumn{2}{|c|}{$\sim 715$} \\
Commentary & Inclusion in chalcopyrite & Inclusion in gersdorfite & Inclusion in violarite
\end{tabular}
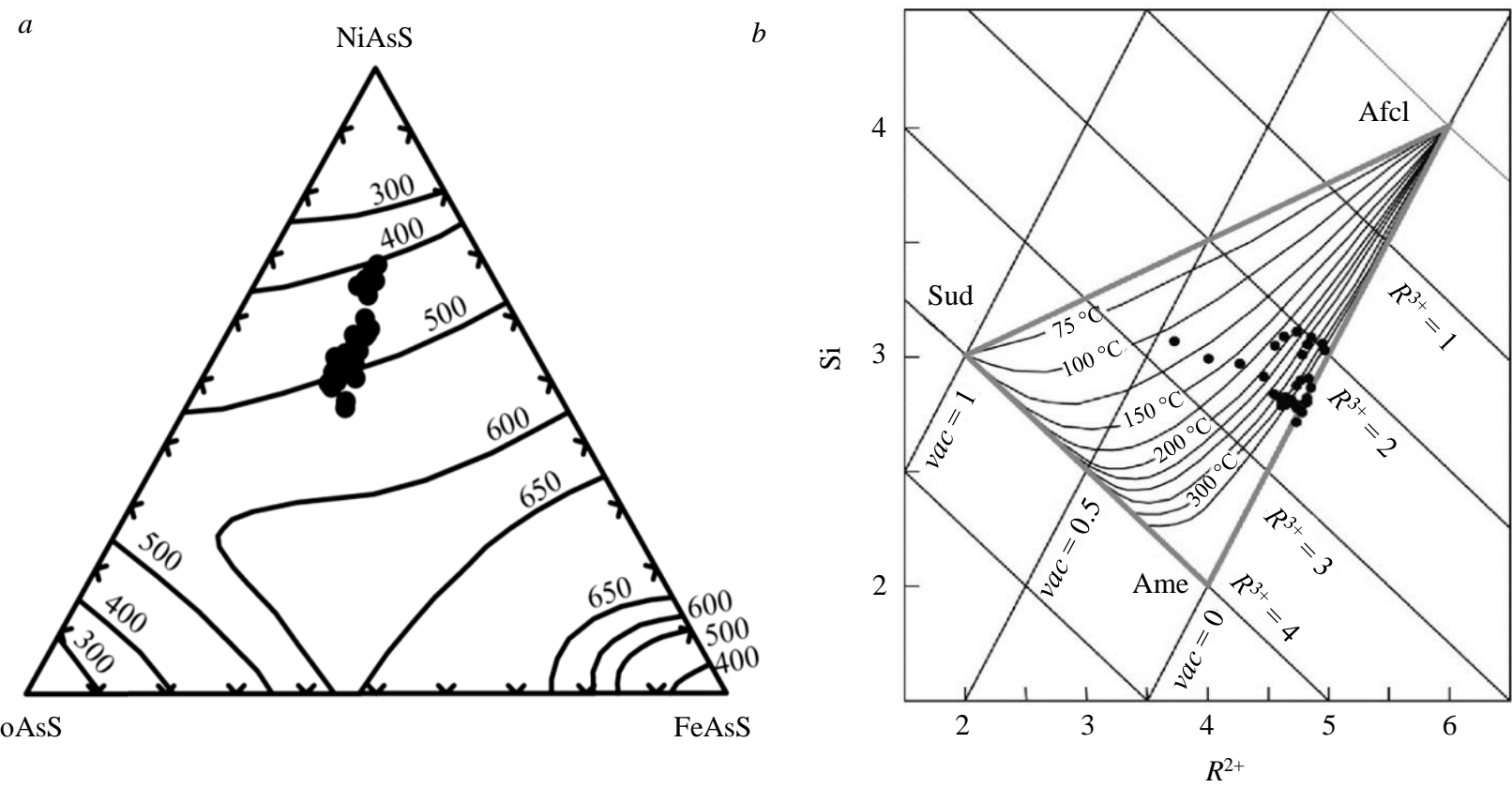

Fig.5. Geothermometer diagram for sulfarsenides in the coordinates NiAsS-FeAsS-CoAsS $(a)$ and for chlorites in the coordinates $\mathrm{R}^{2+}$ (sum of $\mathrm{Fe}^{2+}$ and $\mathrm{Mg}^{2+}$ ) - $\mathrm{Si}(b)$ :

$a$-position of figurative points, corresponding to the compositions of sulfarsenide I, solvus lines under different temperatures $\left({ }^{\circ} \mathrm{C}\right)$ are presented according to [31]; $b$ - diagram of semi-empirical chlorite geothermometer according to [26]; data from 31 tests were used, including the ones from Table 6; Sud - sudoite, Ame - amesite, Afcl - Al-free chlorite, $\mathrm{R}^{3+}-$ trivalent cations $\left(\mathrm{Fe}^{3+}, \mathrm{Al}^{3+}\right)$, vac - vacancy in the octahedral shell

Clinochlore is observed to integrow with $\mathrm{Te}$ and $\mathrm{Bi}$ compounds and associated chalcopyrite and pyrite (see Fig. 2,l). This presents an opportunity to estimate formation conditions of the late noble metal mineralization using chlorite and pyrite-pyrrhotite geothermometers. The temperature of clinochlore formation was estimated using empirical chlorite geothermometers according to [27] and [30], and a semi-empirical one according to [26]. Geothermometers according to [27, 30] are based on the linear correlation of $\mathrm{T}^{\circ} \mathrm{C}-\mathrm{Al} I \mathrm{IV}$ in chlorites. Temperature estimates obtained according to [27] vary from 119 to $337^{\circ} \mathrm{C}$; the ones obtained according to [30] - from 124 to $335^{\circ} \mathrm{C}$ (Table 6).

Compositions of clinochlore (wt.\%)

\begin{tabular}{l|c|c|c|c|c|c}
\hline \multirow{2}{*}{ Component } & \multicolumn{2}{|c|}{$\mathrm{A} 107-1$} & A113-7 & \multicolumn{2}{c|}{ A113-5 } & GR7 \\
\cline { 2 - 7 } & 1 & 2 & 3 & 4 & 5 & 6 \\
\hline $\mathrm{SiO}_{2}$ & 27.51 & 28.18 & 28.30 & 29.60 & 30.35 & 32.17 \\
$\mathrm{TiO}_{2}$ & - & - & - & - & - & - \\
$\mathrm{Al}_{2} \mathrm{O}_{3}$ & 20.15 & 18.81 & 20.88 & 17.42 & 16.78 & 12.77 \\
$\mathrm{Cr}_{2} \mathrm{O}_{3}$ & 0.68 & & 0.25 & - & - & - \\
$\mathrm{FeO}$ & 17.23 & 18.80 & 13.10 & 18.00 & 17.19 & 24.21
\end{tabular}


End of Table 6

\begin{tabular}{l|c|c|c|c|c|c}
\hline \multirow{2}{*}{ Component } & \multicolumn{2}{|c|}{$\mathrm{A} 107-1$} & A113-7 & \multicolumn{2}{c|}{ A113-5 } & GR7 \\
\cline { 2 - 7 } & 1 & 2 & 3 & 4 & 5 & 6 \\
\hline $\mathrm{V}_{2} \mathrm{O}_{3}$ & - & - & - & - & 0.36 & - \\
$\mathrm{MnO}$ & - & - & - & - & - & - \\
$\mathrm{MgO}$ & 21.90 & 20.57 & 24.35 & 21.54 & 21.30 & 14.49 \\
$\mathrm{NiO}$ & 0.50 & 0.40 & 0.30 & 0.56 & 0.61 & 1.34 \\
$\mathrm{~K} 2 \mathrm{O}$ & 0.23 & - & - & - & - & - \\
Total & 88.19 & 86.76 & 87.35 & 87.12 & 86.59 & 84.98
\end{tabular}

Number of cations in the formula with 14 atoms of $\mathrm{O}$

\begin{tabular}{|c|c|c|c|c|c|c|}
\hline $\mathrm{Si}$ & 2.763 & 2.901 & 2.797 & 3.013 & 3.094 & 3.439 \\
\hline $\mathrm{Ti}$ & - & - & 0.013 & - & - & - \\
\hline Aliv & 1.238 & 1.100 & 1.204 & 0.988 & 0.907 & 0.561 \\
\hline AlvI & 1.154 & 1.177 & 1.230 & 1.101 & 1.115 & 1.062 \\
\hline $\mathrm{Cr}$ & 0.054 & - & 0.020 & - & - & - \\
\hline $\mathrm{Fe}^{3+}$ & 0.000 & - & 0.034 & 0.034 & 0.100 & 0.265 \\
\hline $\mathrm{Fe}^{2+}$ & 1.470 & 1.586 & 1.045 & 1.477 & 1.353 & 1.887 \\
\hline $\mathrm{Mn}$ & - & - & - & - & - & - \\
\hline $\mathrm{Mg}$ & 3.278 & 3.157 & 3.587 & 3.268 & 3.237 & 2.310 \\
\hline $\mathrm{Ni}$ & 0.041 & 0.033 & 0.024 & 0.046 & 0.050 & 0.115 \\
\hline $\mathrm{K}$ & 0.059 & - & - & - & - & - \\
\hline & 8.000 & 8.000 & 8.000 & 8.000 & 8.000 & 8.000 \\
\hline $\mathrm{Fe}^{2+} /\left(\mathrm{Fe}^{2+}+\mathrm{Mg}\right)$ & 0.31 & 0.33 & 0.23 & 0.31 & 0.29 & 0.45 \\
\hline \multicolumn{7}{|c|}{$T,{ }^{\circ} \mathrm{C}[27]$} \\
\hline & 337 & 292 & 326 & 256 & 230 & 119 \\
\hline \multicolumn{7}{|c|}{$T,{ }^{\circ} \mathrm{C}[31]$} \\
\hline & 335 & 292 & 322 & 256 & 230 & 124 \\
\hline
\end{tabular}

Note. The ratio of $\mathrm{Fe}^{2+} / \mathrm{Fe}^{3+}$ and number of $\mathrm{OH}$ ions were calculated assuming complete filling of shells
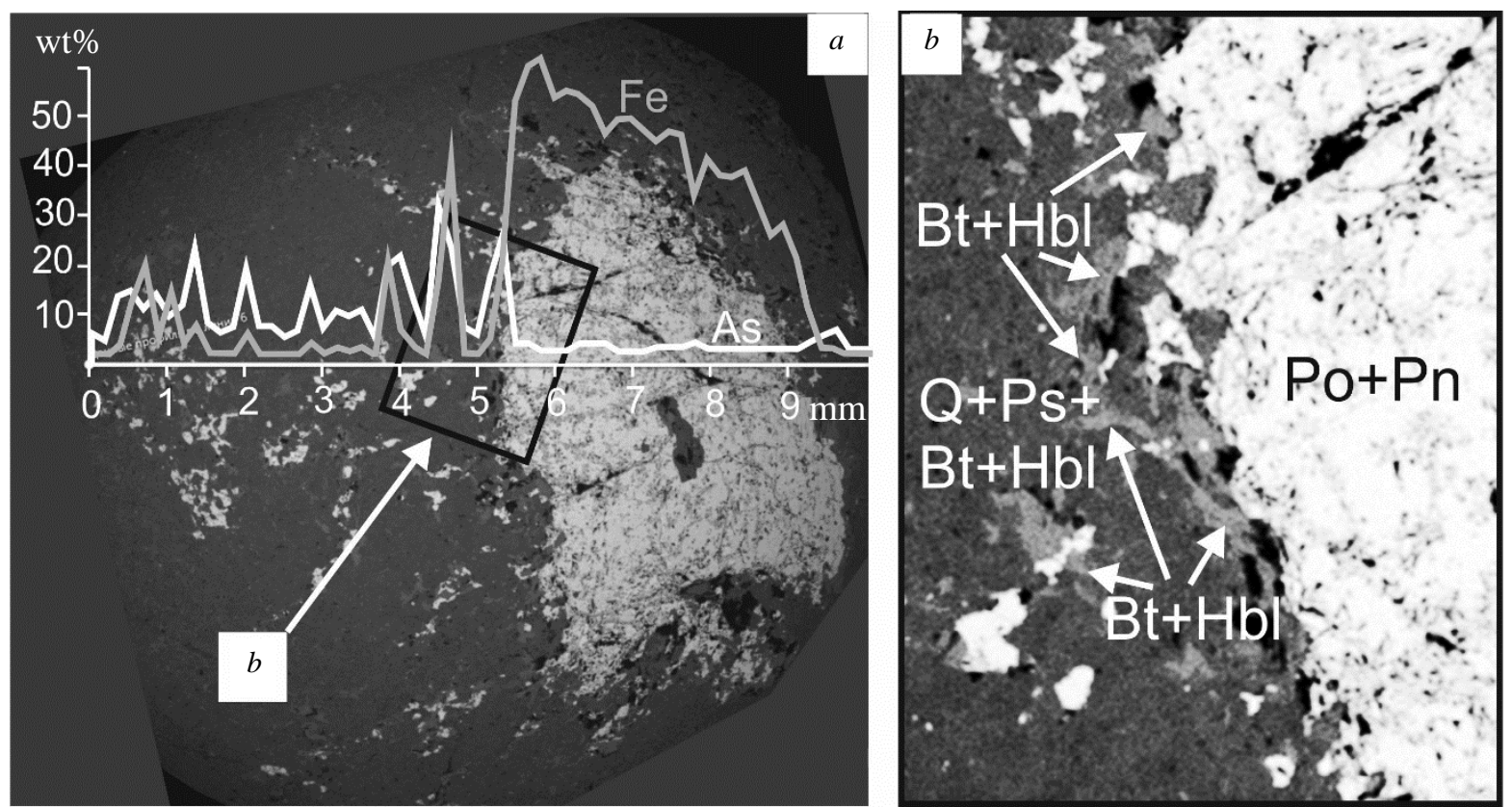

Fig.6. The distribution pattern of arsenides and sulfarsenides in the rim of a large inclusion, composed of pyrrhotite and pentlandite, in the mass of post-ore granitoids:

$a$ - pyrrhotite segregation with pentlandite growths (light grey area), around $5 \mathrm{~mm}$ in size, in the vein hosted by plagiogranite (dark grey background), composed of quartz and feldspar (prevailing minerals), as well as biotite and hornblende. A large sulfide spot is surrounded by scattered small fragments of sulfides, tenth-hundredth of a millimeter in size, as well as by biotite and hornblende; $b$ - a magnified fragment of the contact between the large sulfide inclusion $(\mathrm{Po}+\mathrm{Pn})$ and plagiogranite, the rimming of sulfide grains by biotite $(\mathrm{Bt})$ and hornblende $(\mathrm{Hbl})$ is clearly visible in the main mass of quartz and feldspar $(\mathrm{Q}+\mathrm{Ps})$. 
The semi-empirical chlorite geothermometer according to [26] is a diagram in the coordinates $\mathrm{R}^{2+}$ (sum of $\mathrm{Fe}^{2+}$ and $\mathrm{Mg}^{2+}$ ) - Si (see Fig.5, $b$ ). The formulas were calculated for 14 atoms of oxygen, all iron was assumed to be divalent. According to this diagram, estimated temperatures of clinochlore formation vary from $\sim 110$ to more than $300{ }^{\circ} \mathrm{C}$.

Pyrrhotite with increased sulfur content, the composition of which is close to $\mathrm{Fe}_{6} \mathrm{~S}_{7}$, forms a part of the pyrite-marcasite mineral association. It occurs in paragenesis with pyrite, which forms under equilibrium thermodynamic conditions in the process of hydrothermal transformations. There is no contradiction between this fact and the observed ratios of nickel and cobalt in pyrites and pyrrhotites, which presents an opportunity to estimate the temperatures using a geothermometer according to [2], based on Co distribution between these minerals (Table 7). The calculated temperatures, obtained using average Co content, vary from 263 to $323{ }^{\circ} \mathrm{C}$ (Table 7, average value of $\sim 296{ }^{\circ} \mathrm{C}$ ) [2]. In this case, the estimate for $\mathrm{Ni}$ is incorrect, since its concentration in pyrites exceeds $1.5 \mathrm{wt} \%$. As a result, the isotherms of $\mathrm{Ni}$ distribution between pyrite and pyrrhotite deviate from the straight-line relationship [2].

Co distribution between pyrrhotite and pyrite and formation temperature of pyrite-pyrrhotite paragenesis according to [2] (pyrite-marcasite mineral association)

\begin{tabular}{l|c|c|c|c|c|}
\hline \multirow{2}{*}{ Sample No. } & \multicolumn{2}{|c|}{ Co content, wt.\% } & \multicolumn{2}{c|}{$\left(\right.$ Co, at.\%/Fe, at.\%) $\cdot 10^{-2}$} & $K_{\mathrm{D}}{ }^{\mathrm{Co}}$ \\
\cline { 2 - 5 } & Pyrrhotite & Pyrite & Pyrrhotite & Pyrite \\
\hline A113-7 & $0.38(n=6)$ & 0.70 & 0.920 & 1.700 & 0.375 \\
GR10 & $0.32(n=6)$ & $0.48(n=4)$ & 0.690 & 1.050 & 0.493 \\
GR7 & $0.52(n=2)$ & 0.45 & 1.170 & 1.010 & 0.837
\end{tabular}

Note. The estimation of Co content in pyrite and pyrrhotite was based on the average of values measured in different points of the same sample; $n$ - number of measurements; $K_{\mathrm{D}}{ }^{\mathrm{Co}}-$ coefficient of Co distribution between pyrite and pyrrhotite.

Discussion of results. The segregation of early noble metal minerals and paragenetically related sulfarsenide I occurs in the following sequence: sperrylite $\rightarrow$ irarsite $\rightarrow \mathrm{Pt}+\mathrm{Ir}+\mathrm{Te}$ phase $\rightarrow$ sulfarsenide I (with traces of platinoids). The earliest platinum mineral is sperrylite. It is possibly of magmatic origin, and its segregates act as crystallization centers for other platinoid minerals and $\mathrm{Fe}-$ Co-Ni sulfarsenides. The contact-metasomatic origin of sulfarsenide I is explained by the intrusion of post-ore granitoids, which is proved by the ratios of minerals, illustrated in Fig. 6. In Fig. 6, a 5$\mathrm{mm}$ pyrrhotite inclusion is enclosed in a vein hosted by plagiogranite, which is composed of an orthoclase-oligoclase-quartz aggregate with inclusions of biotite and hornblende. A large sulfide segregation is rimmed by chains of smaller, acute-angled sulfide inclusions. All the grains of ore minerals in the quartz-feldspar aggregate are surrounded by reaction rims of biotite and magnesio-hornblende (Fig. 6, b). Observed proportions indicate the fragmentation of the large sulfide grain in the process of granitoid intrusion, accompanied by the formation of dark-colored silicates around the sulfides as a result of contact-metasomatic processes.

The plot of As contents, a cross-section through the large sulfide grain and surrounding plagiogranite (Fig. 6,a) demonstrates that arsenides and sulfarsenides are attracted to accumulations of biotite and hornblende, rimming small ore grains in plagiogranite, whereas the large sulfide segregation contains no As-bearing phases. Hence, formation of sulfarsenides, as well as the rims of darkcolored minerals around sulfides, is related to contact-metasomatic processes. It is also accompanied by redistribution of PGEs, associated with syngenetic sulfide ores, which results in the formation of irarsite and the $\mathrm{Pt}+\mathrm{Ir}+\mathrm{Te}$ phase, paragenetically related to sulfarsenide I.

The absence of ore melting signs in the near-contact area of the post-ore intrusion of granitoids correlates with experimental and calculated data. The melting of sulfide mineral associations occurs in the temperature interval from 850 to $1200{ }^{\circ} \mathrm{C}$ [10]. At the same time, estimations of formation 


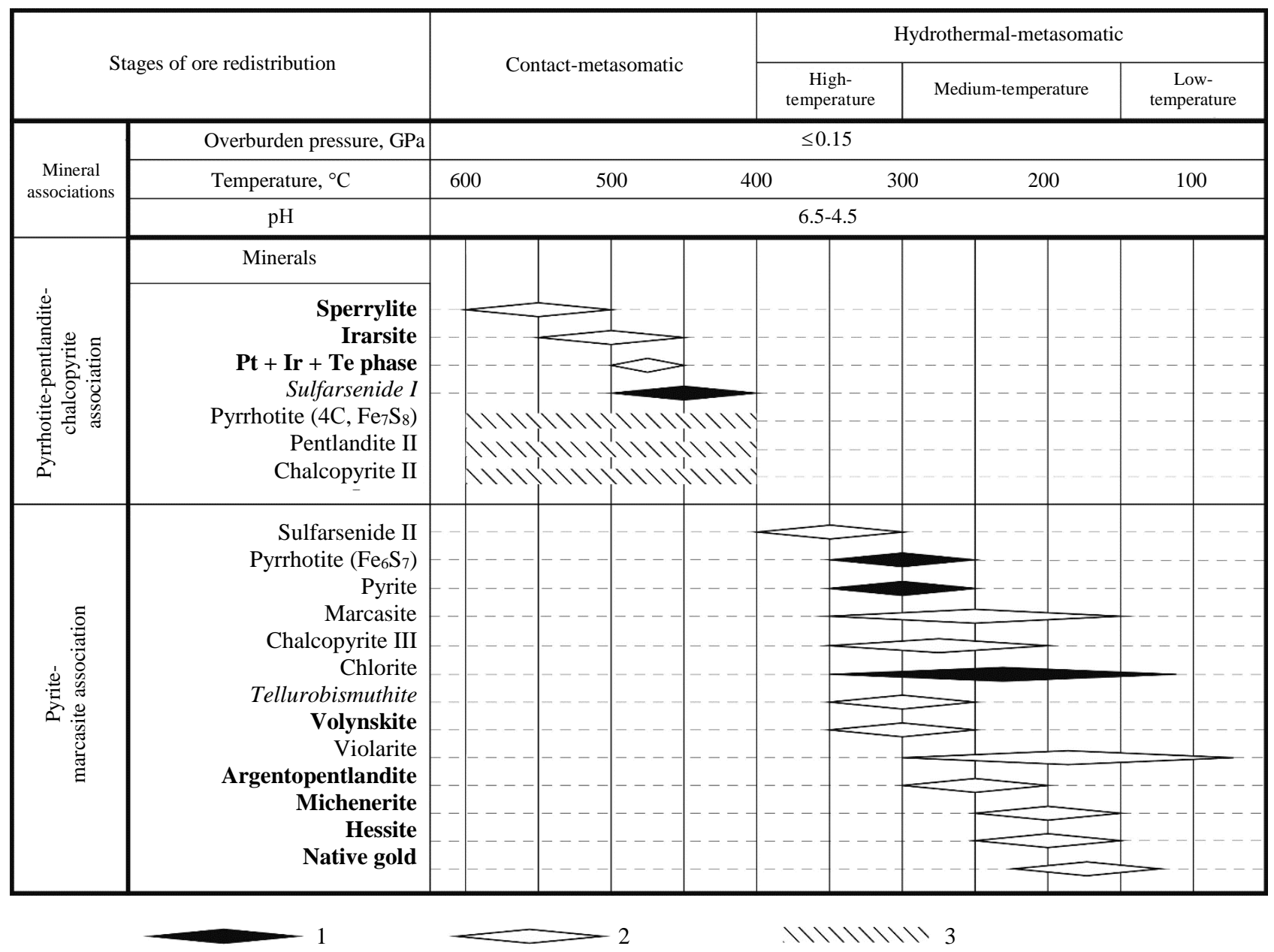

Fig.7. A chart representing the sequence and conditions of formation for noble metal minerals (in bold), minerals with isomorphic traces of noble metals (in italics), associated main and widely-occurring sulfides and chlorites at the Annabergitovaya Schel ore occurrence (using data from [13])

1 - formation conditions are estimated using geothermometers and mineral ratios; 2 - only mineral ratios and indirect data; 3 - solid-phase transformations without resulting formation of new mineral species

conditions for hornblende in the petrotypical massif of granitoids of the Kola complex are less extreme: $513-552{ }^{\circ} \mathrm{C}$ at pressure of $0.17-0.21 \mathrm{GPa}$ [22]. These conditions correspond to the estimated formation temperatures of sulfarsenide I and associated early platinoid sulfarsenides $\left(400-500{ }^{\circ} \mathrm{C}\right.$, Fig.5, $a$ ), as well as to the capture temperatures of fluid inclusions in quartz from the ores of the Shanuch deposit $\left(\sim 400-500{ }^{\circ} \mathrm{C}\right)$ [8]. Taken together, all these data are consistent with the formation conditions of quartz-feldspar metasomatites [1], which are in equilibrium with circumneutral solutions ( $\mathrm{pH}$ of 4.5-6.5) at temperatures of $350-600{ }^{\circ} \mathrm{C}$, depths of $\leq 5 \mathrm{~km}$ and pressure below $\sim 0.15 \mathrm{GPa}$ (Fig.7).

At the late hydrothermal-metasomatic stage, the following formation sequence of noble metal minerals is observed: tellurobismuthite $\rightarrow$ volynskite (an aggregate of tsumoite (?) and volynskite) $\rightarrow$ argentopentlandite $\rightarrow$ michenerite + hessite. Formation of native gold probably did not occur before the formation of tellurides. Glaucodot (sulfarsenide II), which is known as a hightemperature hydrothermal mineral, probably belongs to the same stage of mineral formation. Due to hydrothermal origin of glaucodot, the diagram from [31] is inapplicable to it, since it has been developed for "dry" systems [6].

Hydrothermal-metasomatic transformations of ores, associated with late noble metal mineralization, pyrite, marcasite, and clinochlore-epidote-actinolite paragenesis, are close to propylitization processes at $\mathrm{pH}$ values of 4.5-6.5 and temperatures of $150-350{ }^{\circ} \mathrm{C}$ at depths $\leq 5 \mathrm{~km}$ [1]. It is confirmed 
by estimated formation temperatures for chlorites (from 110 to $340{ }^{\circ} \mathrm{C}$ ), pyrites and late pyrrhotites (around $296{ }^{\circ} \mathrm{C}$ ). The connection of clinochlore-epidote-actinolite paragenesis to $\mathrm{Bi}$ and $\mathrm{Te}$ compounds emphasizes its medium- to low-temperature nature: the formation temperatures of tellurides are less than $350{ }^{\circ} \mathrm{C}$, usually below $250{ }^{\circ} \mathrm{C}$ [25], and hessite is one of characteristic minerals of lowtemperature hydrothermal associations. The exception in this case is provided by the $\mathrm{Pt}+\mathrm{Ir}+\mathrm{Te}$ phases, segregated together with sulfarsenide I (Fig.7).

Conclusion. Cobalt-copper-nickel sulfide ores of the KNP, containing noble metals, were formed as a result of magmatic differentiation in the process of intrusion development in the Dukuk complex of the norite-cortlandite formation and further epimagmatic transformations. Performed studies allowed to specify the characteristics of material composition of platinoid, silver, gold, bismuth and tellurium minerals, as well as closely associated sulfarsenides in the ores of one of the KNP ore occurrences - Annabergitovaya Schel. Identification of the sequence of mineral formation and the use of geosensors made it possible to estimate the formation conditions for the minerals of PGE, silver and gold.

The formation of noble metal minerals at the Annabergitovaya Schel ore occurrence is mainly caused by epigenetic processes; magmatic origin can only be assumed for sperrylite.

The early, contact-metasomatic, stage is associated with intrusion of post-ore granitoids. It led to the development of an association of sperrylite, irarsite, rare unnamed phases of $\mathrm{Pt}+\mathrm{Ir}+\mathrm{Te}$ and sulfarsenide I. According to [31], the formation temperature of sulfarsenide I is $400-500{ }^{\circ} \mathrm{C}$. It agrees with the estimated conditions for the formation of quartz-feldspar metasomatites - at temperatures of $350-600{ }^{\circ} \mathrm{C}$ and depths of $\leq 5 \mathrm{~km}$ (pressure of $\sim \leq 0.15 \mathrm{GPa}$ ), in equilibrium with circumneutral solutions $(\mathrm{pH}$ of 4.5-6.5) [1].

Argentopentlandite, volynskite, native gold, michenerite and hessite were formed as a result of late high- to medium-temperature hydrothermal-metasomatic transformations. The association of hydrothermal minerals, paragenetically related to them, is close to propylites. The conditions of propylization - at depths of $\leq 5 \mathrm{~km}(\sim \leq 0.15 \mathrm{GPa}), \mathrm{pH}$ values of 4.5-6.5 and temperature of $150-350{ }^{\circ} \mathrm{C}$ [1] - are consistent with the temperature estimates, obtained with pyrite-pyrrhotite (about $296^{\circ} \mathrm{C}$ ) and chlorite geothermometers (from 110 to $340{ }^{\circ} \mathrm{C}$ ).

Acknowledgements. The authors express their gratitude to V.M.Chubarov, V.A.Stepanov for useful discussion of the paper, and to N.V.Gorbach for critical comments on the text.

\section{REFERENCES}

1. Bardina N.Yu., Popov V.S. Systematics of Metasomatic Rocks and Facies of Shallow-Depth Metasomatism. Sovetskaya geologiya. 1991. N 6, p. 48-56 (in Russian).

2. Bezmen N.I., Tikhomirova V.I., Kosogova V.P. Pyrite-Pyrrhotite Geothermometer: Distribution of Nickel and Cobalt. Geokhimiya. 1975. N 5, p. 700-715.

3. Spiridonov E.M., Kulagov E.A., Serova A.A. et al. Genetic PD, PT, AU, AG, and RH Mineralogy in Norilsk Sulfide Ores. Geology of Ore Deposits. 2015. Vol. 57. N 5, p. 402-432. DOI: $10.1134 /$ S1075701515050062

4. Radomskaya T.A., Glazunov O.M., Vlasova V.N., Suvorova L.F. Geochemistry and mineralogy of platinum group element in ores of the Kingash deposit, Eastern Sayan, Russia. Geology of Ore Deposits. 2017. Vol.59, N 5, p.354-374. DOI: $10.1134 / \mathrm{S} 107570151705004 \mathrm{X}$

5. Slyadnev B.I., Shapovalenko V.N., Krikun N.F. et al. State Geological Map of the Russian Federation at a Scale of 1: 1,000,000 (third generation). Sheet N-57. Petropavlovsk-Kamchatsky. Explanatory letter. St. Petersburg: Kartfabrika VSEGEI, 2007, p. 187 (in Russian).

6. Gritsenko Yu.D., Spiridonov E.M. Sulfarsenides and Sulfantimonides of Nickel, Cobalt, Iron and Krutovite in Metamorphogenic-Hydrothermal Carbonate Veins of the Norilsk Ore Field. Novye dannye o mineralakh. 2006. N 41, p. 46-55.

7. Zimin S.S. Formation of Nickel-Bearing Hornblende Basites of the Far East. Novosibirsk: Nauka, 1973, p. 90.

8. Konnikov E.G., Vasyukova O.N. Composition of Fluid Inclusions from Intrusive Rocks of the Norite-Cortlandite Complex, Kamchatka. Geology of Ore Deposits. 2007. Vol. 49. N 3, p. 227-237. DOI: 10.1134/S1075701507030063

9. Kungurova V.Ye., Stepanov V.A., Trukhin Yu.P. Copper-Nick-El Ore Occurrence Annabergitovaya Schel in the Kamchatka's Nickel-Province. Mining informational and analytical bulletin. 2014. N S2, p. 324-333 (In Russian).

10. Likhachev A.P. Platinum-Copper-Nickel and Platinum Deposits. Moscow: Eslan, 2006, p. 495 (in Russian).

11. Chubarov V.M., Ignatev E.K., Moskaleva S.V. et al. The Kvinum-1 Copper-Nickel Prospect in Cortlandites, the Southern Sredinnyi Range, Kamchatka. Doklady Earth Sciences. 2005. Vol. 403. N 5, p. 710-714. 
12. Novakov R.M., Trukhin Yu.P., Kungurova V.E. et al. The Vostochno-Geophizichesky Allotment of the Shanuch Sulphide Copper-Nickel Deposit (Kamchatka). Bulletin of Kamchatka Regional Association "Educational-Scientific Center" Earth Sciences. 2017. Vol. 33. N 1, p. 34-45 (in Russian).

13. Stepanov V.A., Gvozdev V.I., Trukhin Yu.P. et al. Minerals of Precious and Rare Metals in Ores of Shanuchskoye CopperNickel Deposit (Kamchatka). Zapiski Rossiiskogo mineralogicheskogo obshchestva. 2010. Vol. 139. N 2, p. $43-58$ (In Russian).

14. Larichkin F.D., Novoseltseva V.D., Glushchenko Yu.G., Naumova M.V. Platinoids: resources, production, markets and perspectives. Journal of Mining Institute. 2013. Vol. 201, p. 39-42.

15. Poletaev V.A. Sulfide Platinoid-Copper-Nickel Deposits and Ore Occurrences of the Peridotite-Pyroxenite-Norite Formation in Central Kamchatka. Platina Rossii. Vol. III. B. 2. Moscow: ZAO “Geoinformmark”, 1999, p. 191-199 (in Russian).

16. Rakhimov I. R., Saveliev D. E., Vishnevskiy A.V. Sulfide-platinum metal mineralization of Khudolaz complex Malyutka altered gabbro massif: hydrothermal influence to the mineral association types. Vestnik of Institute of Geology of Komi Science Center of Ural Branch RAS. 2019. N 7(295), p. 15-24. DOI: 10.19110/2221-1381-2019-7-15-24 (in Russian)

17. Selyangin O.B. Magma Contamination, Petrogenesis Features Anddistribution of Ore Element in the Rocks of Nickeliferousformation in the Sredinny-Kamchatka Massif. Bulletin of Kamchatka Regional Association "Educational-Scientific Center" Earth Sciences. 2018. Iss. 4. N 40, p. 5-22. DOI: 10.31431/1816-5524-2018-4-40-5-22 (in Russian).

18. Selyangin O.B. Petrology of the Nickel-Bearing Basic Rocks of the Shanuch Ore Field. Bulletin of Kamchatka Regional Association "Educational-Scientific Center". Earth Sciences. 2003. N 2, p. 33-55 (in Russian).

19. Simakin A.G., Zakrevskaya O.Yu., Salova T.P. Estimation of Crystallization Conditions for Kamchatka Cortlandites Using Amphibole Compositions. Vestnik Otdeleniya nauk o Zemle Rossiiskoi akademii nauk. 2012. Vol. 4. N NZ9001. DOI:10.2205/2012NZ_ASEMPGR40 (in Russian).

20. Kungurova V.Ye., Stepanov V.A., Trukhin Yu.P., Novakov R.M. Ores Composition of Copper-Nickel Occurrence Annabergite Schel (Kamchatka). Gornyi informatsionno-analiticheskii byulleten. 2016. N S31, p. 42-55. (In Russian)

21. Stepanov V.A., Melnikov A.V. Nickel Presence in the Upper Amur Region. Vladivostok: Dalnauka, 2010, p. 217 (in Russian).

22. Tararin I.A., Badredinov Z.G., Chubarov V.M. Petrology and Ore-Bearing Capacity of Metamorphic and Magmatic Complexes of Central and Eastern Kamchatka. Vladivostok: Dalnauka, 2015, p. 302 (in Russian).

23. Trukhin Yu.P., Stepanov V.A., Sidorov M.D. Kamchatka Nickel-Bearing Province. Doklady Akademii nauk. 2008. Vol. 418. N 6, p. 802-806 (in Russian).

24. Chernyshov N.M., Chernyshova M.N. Peculiarities of distribution and a model for the mechanism of fractionation of platinum group metals in sulfide nickel ores of the elan-type deposits. Paper 2. Geologic and genetic nature of ore-magmatic system of the yelan type and fractionation mechanism in PGM ores. Proceedings of Voronezh state university. Series: Geology. 2011. N 2, p. 148-167.

25. Afifi A.M., Kelly W.C., Essene E.J. Phase relations among tellurides, sulfides, and oxides; Pt. II, Applications to telluridebearing ore deposits. Economic Geology. 1988. Vol. 83(2), p. 395-404. DOI: 10.2113/gsecongeo.83.2.395

26. Bourdelle F., Cathelineau M. Low-temperature chlorite geothermometry: A graphical representation based on a T-R ${ }^{2+}-\mathrm{Si}$ diagram. European Journal of Mineralogy. 2015. Vol. 27(5), p. 617-626. DOI: 10.1127/ejm/2015/0027-2467

27. Cathelineau M. Cation site occupancy in chlorites and illites as a function of temperature. Clay Miner. 1988. Vol. 23. Iss. 4, p. 471-485. DOI: 10.1180/claymin.1988.023.4.13

28. Dare S.A.S., Barnes S.-J., Prichard H.M., Fisher P.C. Chalcophile and platinum-group element (PGE) concentrations in the sulfide minerals from the McCreedy East deposit, Sudbury, Canada, and the origin of PGE in pyrit. Mineralium Deposita. 2011. Vol. 46, p. 381-407. DOI: 10.1007/s00126-011-0336-9

29. Piña R., Gervilla F., Barnes S.-J., Ortega L., Lunar R. Distribution of platinum-group and chalcophile elements in the Aguablanca Ni-Cu sulfide deposit (SW Spain): Evidence from a LA-ICP-MS study. Chemical Geology. 2012. Vol. 302-303, p. 61-75. DOI: $10.1016 /$ j.chemgeo.2011.02.010

30. Jowett E.C. Fitting iron and magnesium into the hydrothermal chlorite geothermometer. GAC/MAC/SEG Joint Annual Meeting. Toronto. May 27-29. 1991. Program with Abstracts 16. A62.

31. Klemm D.D. Syntheses and analyzes in the triangle diagrams FeAsS-CoAsS-NiAsS and $\mathrm{FeS}_{2}-\mathrm{CoS}_{2}-\mathrm{NiS}_{2}$. Neues Jahrb. Mineral. 1965. Abh. 103, p. 205-255 (in German).

32. Krivolutskaya N.A., Sobolev A.V., Snisar S.G. et al. Mineralogy, geochemistry and stratigraphy of the Maslovsky Pt-CuNi-sulfide deposit, Noril'sk Region, Russia: Implications for relationship of ore bearing intrusions and lavas. Mineralium Deposita. 2012. Vol. 47, p. 69-88. DOI: 10.1007/s00126-011-0372-5

33. Naldrett A.J. Magmatic sulfide deposits - Geology, Geochemistry, and Exploration. Berlin: Springer-Verlag, 2004 , p. 727.

Authors: Roman M. Novakov, Candidate of Geological and Mineralogical Sciences, Senior Researcher,6rom6@mail.ru, https://orcid.org/0000-0003-2388-6425 (Scientific Research Geotechnological Centre of the Far Eastern Branch of the Russian Academy of Sciences, Petropavlovsk-Kamchatsky, Russia), Valentina E. Kungurova, Candidate of Geological and Mineralogical Sciences, Leading Researcher, kunwe@yandex.ru, https://orcid.org/0000-0001-6565-9808 (Scientific Research Geotechnological Centre of the Far Eastern Branch of the Russian Academy of Sciences, Petropavlovsk-Kamchatsky, Russia), Svetlana V. Moskaleva, Researcher, svemos@rambler.ru, https://orcid.org/0000-0002-8494-6332 (Institute of Volcanology and Seismology of the Far Eastern Branch of the Russian Academy of Sciences, Petropavlovsk-Kamchatsky, Russia).

The authors declare no conflict of interests.

The paper was received on 9 September, 2020.

The paper was accepted for publication on 29 March, 2021. 